\title{
Astrocytes, emerging stars of energy homeostasis
}

\author{
Simonetta Camandola ${ }^{1, *}$ \\ ${ }^{1}$ Laboratory of Neurosciences, National Institute on Aging, Intramural Research Program, Baltimore, MD, USA. \\ * Corresponding Author: \\ Simonetta Camandola, Laboratory of Neurosciences, National Institute on Aging, Intramural Research Program, 251 Bayview Blvd, \\ Baltimore, MD, 21224, USA; Tel: +1 410558 8617; E-mail: camandolasi@mail.nih.gov
}

\begin{abstract}
Astrocytes have historically been considered structural supporting cells for neurons. Thanks to new molecular tools, allowing specific cell ablation or over-expression of genes, new unexpected astrocytic functions have recently been unveiled. This review focus on emerging groundbreaking findings showing that hypothalamic astrocytes are pivotal for the regulation of whole body energy homeostasis. Hypothalamic astrocytes sense glucose and fatty acids, and express receptors for several peripheral hormones such as leptin and insulin. Furthermore, they display striking sexual dimorphism which may account, at least partially, for gender specific differences in energy homeostasis. Metabolic alterations have been shown to influence the initiation and progression of many neurodegenerative disorders. A better understanding of the roles and interplay between the different brain cells in regulating energy homeostasis could help develop new therapeutic strategies to prevent or cure neurodegenerative disorders.
\end{abstract}

doi: $10.15698 / c s t 2018.10 .157$

Received originally: 12.06.2018;

in revised form: 26.08.2018,

Accepted 15.09.2018.

Published 29.09.2018.

Keywords: astrocytes,

hypothalamus, metabolism.

\section{Abbreviations:}

ApoE - apolipoprotein $E$ ERa-estrogen receptor alpha

GABA - v-aminobutyric acid.

\section{INTRODUCTION}

The brain is the organ responsible for the centralized control of the other organs' functions and, in higher vertebrates, of reasoning. Such tasks are achieved thanks to the interconnections of billions of neurons and glia cells. Due to their role in receiving, processing, and transmitting information neurons are considered to be the primary cell types of the central nervous system, and the only repository of reasoning and awareness. Astrocytes are the most abundant type of glial cells [1]. Given their 'not electrically excitable' nature, it has long been assumed that astrocytes merely act as structural supporting cells for neurons. However, phylogenetic and recent experimental evidence corroborate the idea that glia in general, and astrocytes in particular, may have played a direct role in the establishment of higher cognitive function. While the rat cerebral cortex contains roughly 0.4 glia to neuron cells [2], the human highly evolved neocortex has a ratio of $1.4[3,4]$. The same overall increase is also observed within a species based on the evolutionary stage $[2,5]$, and the neuronal density of the brain area considered [6]. Rather than to brain size the change seems to correlate to the average neuronal size and is independent from neuronal metabolic requirements [6]. While the number of neurons is not proportional to the size of the brain, there is an almost linear correlation amongst non-neuronal cell density and brain mass in species spanning 90 million of years of evolution [7]. This suggests the existence of an evolutionary conserved mechanism to add glial cells to the brain as its size and/or complexity increased [8]. It also infers that the functions of glial cells are so fundamental for brain physiology to have been maintained for millions of years of evolution [6]. It was recently shown that the engraftment of mice with human derived astrocytes increases activity dependent plasticity and learning compared to the rodent engrafted counterparts [9]. Alterations in astrocyte function result in impairment of slow wave synchronicity and sleep [10], memory consolidation [11], and associative memory [12], strongly substantiating their involvement in rhythm generation and neural network patterning. At a cellular level, it has been established that astrocytes are instrumental for modulating synaptic plasticity by regulating the formation, maintenance and removal of synapses [13], the rate of local cerebral blood flow and the volume of the extracellular space [14], the secretion or removal of neurotransmitters from the synaptic cleft $[15,16]$. Furthermore, brain energy production, delivery and storage heavily rely on the astrocytic repertoire of receptors, channels, transporters, and enzymes. The wealth of progress in the understanding of the bidirectional metabolic coupling 
between neurons and astrocytes, and its impact on brain metabolism and cognition has been extensively reviewed over the past years [17-21]. This short review will focus on emerging evidence showing that astrocytes are not only essential for brain function and metabolism, but also contribute to whole body energy homeostasis.

\section{HYPOTHALAMIC ASTROCYTES AS NUTRIENT SENSORS}

The hypothalamus is the portion of the brain that integrates sensory inputs from the external environment with hormonal and neural signals from the body, allowing ad hoc short- and long-term homeostatic adjustments [22]. As a result of the coordinated output of several neuronal networks, the hypothalamus is involved in the control of satiety and hunger, body temperature, sleep, circadian rhythms, thirst [23-25]. From an anatomical point of view, the hypothalamus shows unique features compared to the rest of the brain. The medial-ventral portion of the hypothalamus (i.e. median eminence, vascular organ of the lamina terminals, subfornical organ) is characterized by the absence of blood-brain barrier and extensive vascularization with highly fenestrate capillaries $[26,27]$. Similar, fenestrated capillarization is also observed in the ventromedial area and the nucleus arcuate $[28,29]$. This peculiar vascularization bestows these areas the ability to release hypothalamic hormones in the general blood stream, as well as the chance to act as sensory hubs. An intricate network of specialized glial cells, tanycytes and astrocytes, regulates the diffusion and response to circulating factors such as peripheral hormones, nutrients and peptides. Glucose is the main energy source of the mammalian brain and astrocytes actively coordinate its uptake, metabolization and storage [19-21]. In the hypothalamus the role of the neuron-astrocyte functional glucose coupling expands beyond the fulfillment of energy requirements. Hypothalamic astrocytes actively cooperate with specialized 'glucose sensitive' neurons [30] in detecting circulating glucose levels, and generating the proper systemic metabolic response. This is suggested by experimental evidence showing that the expression of glucose transporters GLUT1 and GLUT2 in astrocytes is critical for glucose sensing. In rodents, whole body as well as hypothalamic hyperglycemia impairs glucose sensing by lowering the expression of GLUT1 in astrocytes [31]. However, the systemic glucose lowering response induced by hyperglycemia is restored by specific adenovirus-mediated re-expression of GLUT1 in hypothalamic astrocytes [31]. Animals expressing a GLUT2 dominant negative construct that prevents glucose sensing but retains intact transport capacities, are hyperphagic with altered hypothalamic orexin, thyrotropin-releasing hormone and corticotropin-releasing hormone expression [32]. Similarly, GLUT2 knock out mice rescued by pancreatic expression of GLUT1 display temporal anomalies in fasting-refeeding behaviors, impaired hypothalamic orexigenic and anorexigenic neuropeptide expression, and impaired systemic response to a glucose challenge [33]. In genetic complementation experiments, the specific re-expression of GLUT2 in astrocytes, but not in neurons, was able to restore the normal glucagon secretion response to physiological hypoglycemia [34]. Further evidence of the requirement of astrocytes in proper glucose sensing comes from studies using knock out models for connexins. Astrocytes are tightly connected by gap junctions to form a large functional syncytium that allows the selective transmission of nutrients and signaling molecules over long distances [35]. Connexins form hemi-channels that are instrumental for astrocytic network transmission. The siRNA-mediated ablation of connexin 43 in the arcuate nucleus diminishes the release of insulin from the pancreas in response to central glucose upregulation [36]. This finding supports the notion that astrocytic intercommunication is essential to proper central glucose sensing and peripheral response [36]. Under conditions of reduced glucose availability, the body can fulfill its energy requirements by switching from glucose to fatty acids utilization. In the brain, astrocytes are the only cell type able to utilize fatty acids for the synthesis of ketones bodies [37]. Contrary to most brain regions the production of ketones in the hypothalamus is relatively high and, at least for certain fatty acids, glucose dependent $[38,39]$. The oxidation of palmitate, but not oleate, is indeed decreased by glucose via $5^{\prime}$-adenosine monophosphate-activated protein kinase (AMPK)dependent mechanism in hypothalamic but not cortical brain slices [39]. Hypothalamic ketones levels are important to mediate food behavior. Specifically, high ketones production in the arcuate nucleus and ventromedial hypothalamus, signals high fat intake and elicits a reduction in caloric intake [40]. Furthermore, the direct actions of glucose and free fatty acids on sensing neurons in the ventromedial hypothalamus can be overrode by ketones released from astrocytes [40]. Another example of involvement of astrocytes in lipid sensing is given by the observation that intraventricular infusion of apolipoprotein $E$ (ApoE) decreases food intake, while its neutralization with anti-ApoE antibodies stimulates it [41]. Astrocytes are the brain predominant site of cholesterol synthesis [42] and the principal cell type expressing ApoE, thus the most likely effectors of ApoE-mediated food behaviors [41, 43]. Interestingly, both ketones and ApoE have been linked to central leptin signaling. Acetoacetyl-CoA synthase, a neuronal ketone body utilizing enzyme, is selectively induced by leptin in the ventromedial hypothalamus and arcuate nucleus via AMPK inhibition [44]. Leptin can also upregulate ApoE levels [43].

\section{ASTROCYTES AS MEDIATORS OF ENDOCRINE SIGNAL- ING}

The possibility that astrocytes may participate in the regulation of body homeostasis in other ways than direct nutrient sensing is inferred by the fact that they express receptors for hormones involved in energy homeostasis such as leptin [45, 46], ghrelin [47], insulin-like growth factor-1 [48], thyroid hormone [49], glucagon like peptide-1 GLP-1 [50], and insulin [51]. How the specific activation of these receptors in hypothalamic astrocytes impacts metabolism has just began to be explored. Morphological and biochemical 
changes have been shown in hypothalamic astrocytes following hormonal stimulation. For example, changes in circulating levels of leptin modify the expression of astrocytic glucose and glutamate transporters $[52,53]$, as well as the extension of sheathing and synaptic contacts on adjacent neurons [52, 54, 55]. These structural changes result in altered neuronal electrophysiological responses. The astrocytic-specific ablation of the leptin receptor leads to decreased astrocytic projections and coverage of proopiomelanocortin neurons, modulation of the electrical activity of proopiomelanocortin and agouti-regulated protein neurons, and ultimately in the attenuation of the anorexigenic response $[55,56]$. While under normal feeding conditions astrocytic-deficient leptin receptor mice do not show a clear metabolic phenotype $[55,57]$ when challenged with a high fat diet they are partially protected from hyperleptinemia and leptin resistance thus obesity [57]. Consistently, diet-induced obese animals show an increase of hypothalamic astrocytic coverage, as well as specific increase of leptin receptor in glial fibrillary acid protein (GFAP)- positive cells [58]. It has also been suggested that leptin-mediated satiety effects could be facilitated by astrocytes responses to ghrelin. Stimulation of astrocytes with ghrelin modify glutamate and glucose metabolism as well as glycogen storage by decreasing GLUT2, glutamine synthetase and lactate dehydrogenase, and increasing glutamate uptake, glycogen phosphorylase and lactate transporters [47]. Furthermore, ghrelin-mediated increase in food intake could be suppressed by the release of adenosine from activated astrocytes and consequent adenosine receptor A1-mediated inhibition of agoutirelated peptide producing neurons in the nucleus arcuate $[59,60]$. Despite the presence of insulin sensitive glucose transporters GLUT4 and GLUT8 in various areas [21], contrary to peripheral organs, brain glucose fluxes are considered insulin-independent $[61,62]$. However, there is evidence that insulin signaling modulates central and systemic metabolic homeostasis $[63,64]$. The mechanisms of central insulin actions are still poorly understood. It was recently shown that hypothalamic astrocytes insulin signaling is essential to integrate central glucose sensing and systemic glucose metabolism [50]. Utilizing several glial-specific loss of function models Garcia-Caceres and colleagues [50], elegantly demonstrated that the postnatal ablation of insulin receptor in hypothalamic astrocytes modify their morphology, mitochondrial function, and connectivity, resulting in reduced glucose dependent-activation of proopiomelanocortin neurons and impaired systemic response to changes in glycemia.

\section{HYPOTHALAMIC ASTROCYTES SEXUAL DIMORPHISM}

Neurological and neurodegenerative disorders are often characterized by sexual dimorphism in terms of either incidence or severity and progression of the pathology [65]. Sexual dimorphisms at both morphological and physiological levels have been reported for several areas of the brain including cortex, hippocampus, amygdala and hypothalamus [66-68]. In the hypothalamus the morphological changes can be appreciated even in gross anatomy and are particularly striking in astrocytes. Female's astrocytes have a simple bipolar structure rather than the complex stellate shape found in males [69]. Furthermore, the levels of GFAP immunostaining in the arcuate nucleus of males increases from birth throughout adulthood [70]. The presence of receptors for estrogen, androgen and progesterone [71-73] is believed to underlie the dynamic morphological changes and possible different functional responses of hypothalamic astrocytes in males and females [72, 74]. In the preoptic area the levels of astrocytic connexin 43 are regulated by estrogen and progesterone in a sex specific manner [75]. Glial structural changes are seen in the hypothalamic areas both in rodents and humans during the estrous cycle [76, 77]. In non-human primates the glial coverage on gonadotropin-releasing hormone (GnRH) secreting neurons increases, while the number of synaptic contacts decreases following ovariectomy, a phenomenon that can be reverted by estrogen replacement [78]. Mechanistically the steroid-induced morphology changes are due to increased $\gamma$ aminobutyric acid (GABA) signaling via $G_{A B A}$ receptors [79]. The impact of sex hormones on metabolism regulation is well known. Estrogen receptor alpha (ERa) regulates food intake, glucose homeostasis and augments energy expenditure $[80,81]$. Fluctuation in food intake is seen in females based on their menstrual cycle, with the lowest during the preovulatory phase when estrogen peaks [82, 83]. Conversely, higher energy intake and increased fat consumption are seen during the progesterone-controlled luteal phase $[82,83]$. The emerging roles of astrocytes in body energy homeostasis and their clear sexual dimorphism, suggest that they may be instrumental in regulating the different responses of females and males to dietary challenges [84, 85]. Supporting such hypothesis is the evidence that hypothalamic astrogliosis and inflammation following high fat diet are higher in male rodents compared to females $[85,86]$. In vitro experiments show different responses to saturated fatty acids in astrocytes isolated from males and females [86, 87]. In vivo, long term high fat diet increases the levels of estradiol in females, while in males its levels are unchanged and associated with a significant decrease of ERa in the hypothalamus [87]. As ERa activation by estrogen have been shown to protect females from diet induced-obesity $[80,88]$, it is possible that astrocytic hypothalamic ERa levels are pivotal in mediating such differences [87]. Notably, the discrepant hypothalamic inflammatory responses observed in wild type animals following an obesogenic diet [86] are lost in ERa knockout animals $[86,88]$. Consistent with their ability to synthetize cholesterol [42], astrocytes are also the primary steroidogenic cells in the brain [89]. The most prevalent hypothalamic neurosteroids are progesterone and its derivative allopregnanolone [89, 90]. Interestingly, the synthesis of neuroprogesterone has been shown to be upregulated by estradiol in hypothalamic astrocytic cultures from females but not male rats [91]. Experimental evidence suggests that in addition to the better characterized roles in sexual behavior, anxiety, analgesia and sleep [92-96], neu- 
rosteroids may influence energy homeostasis. Levels of allopregnanolone have been associated with changes in food intake and eating disorders in humans $[82,96]$. In rats, administration of allopregnanolone increased the feeding latency, as well as the meal duration and the preference for fat $[97,98]$. Although the specific mechanisms underlying the changes in feeding behavior have not been elucidated, neurosteroid's best characterized molecular function is the modulation of GABA signaling at $G_{A B A}$ receptors [99]. Hypothalamic GABA transmission is instrumental for proper feeding behavior and energy homeostasis [100]. As per other aspects of energy metabolism, recent evidence shows that astrocytes play a pivotal role in GABAmediated food related behavior. Hypothalamic astrocytes morphology drastically changes in response to nutritional status [101]. High-order astrocytic processes shorten during fasting and elongate during fed status [101]. These dynamic changes are associated with modified GABA transmission in adjacent neurons and metabolic dysregulation [101].

\section{CONCLUSIONS}

Metabolic alterations influence the initiation and progression of many neurodegenerative disorders [21]. Clinical evidence shows pre- and early-symptomatic changes in the hypothalamus in patients with Alzheimer's disease, Parkinson's disease, Huntington's disease, and amyotrophic lateral sclerosis [102]. Although the hypothalamus senses and regulates energy homeostasis, not many studies have explored the reciprocal influence of the different cell types in

\section{REFERENCES}

1. Verkhratsky A, and Butt AM (2013). "Numbers: how many glial cells are in the brain?". In: Verkhratsky A, and Butt AM, editors. Glial Physiology and Pathophysiology. Wiley-Blackwell, Publishers, Chichester; pp. 93-96. doi:10.1002/9781118402061

2. Bass NH, Hess HH, Pope A, and Thalheimer C (1971). Quantitative cytoarchitectonic distribution of neurons, glia, and DNa in rat cerebral cortex. J Comp Neurol 143(4): 481-490. doi:10.1002/cne.901430405

3. Friede R (1954). Quantitative share of the glia in development of the cortex. Acta Anat 20(3):290-6. PMID: 13137775

4. Pelvig DP, Pakkenberg H, Stark AK, and Pakkenberg B (2008). Neocortical glial cell numbers in human brains. Neurobiol Aging 29(11): 1754-1762. doi: 10.1016/j.neurobiolaging.2007.04.013

5. Leuba G, and Garey $\sqcup$ (1989). Comparison of neuronal and glial numerical density in primary and secondary visual cortex of man. Exp Brain Res 77(1): 31-38. doi: 10.1007/bf00250564

6. Herculano-Houzel S (2014). The glia/neuron ratio: how it varies uniformly across brain structures and species and what that means for brain physiology and evolution. Glia 62(9): 1377-1391. doi: 10.1002/glia.22683

7. Herculano-Houzel S (2012). The remarkable, yet not extraordinary, human brain as a scaled-up primate brain and its associated cost. Proc Natl Acad Sci U S A 109 (Suppl 1): 10661-10668. doi:

10.1073/pnas.1201895109 managing energy homeostasis, nor their involvement in the progression of neurodegenerative disorders. The neuron-centric and "most impacted area of the brain" focus, together with the over reliance on male animals in preclinical studies, have hindered the elucidation of the biological mechanisms that underly brain energy sensing and management in both genders. Understanding these underpinning biological differences by expanding our scientific focus, could be key in developing strategies for diagnosis and interventions.

\section{ACKNOWLEDGMENTS}

This work was supported by the Intramural Research Program of the National Institute on Aging.

\section{CONFLICT OF INTEREST}

The author declares no conflict of interest.

\section{COPYRIGHT}

(C) 2018 Camandola. This is an open-access article released under the terms of the Creative Commons Attribution (CC BY) license, which allows the unrestricted use, distribution, and reproduction in any medium, provided the original author and source are acknowledged.

Please cite this article as: Simonetta Camandola (2018). Astrocytes, emerging stars of energy homeostasis. Cell Stress 2(10): 246-252. doi: $10.15698 /$ cst2018.10.157
8. Herculano-Houzel S (2011). Not all brains are made the same: new views on brain scaling in evolution. Brain Behav Evol 78(1): 22-36. doi: $10.1159 / 000327318$

9. Han X, Chen M, Wang F, Windrem M, Wang S, Shanz S, Xu Q, Oberheim NA, Bekar L, Betstadt S, Silva AJ, Takano T, Goldman SA, and Nedergaard $M$ (2013). Forebrain engraftment by human glial progenitor cells enhances synaptic plasticity and learning in adult mice. Cell Stem Cell 12(3): 342-353. doi: 10.1016/j.stem.2012.12.015

10. Halassa MM, Florian C, Fellin T, Munoz JR, Lee SY, Abel T, Haydon PG, and Frank MG (2009). Astrocytic modulation of sleep homeostasis and cognitive consequences of sleep loss. Neuron 61(2):213-219. doi: 10.1016/j.neuron.2008.11.024

11. Lee HS, Ghetti A, Pinto-Duarte A, Wang X, Dziewczapolski G, Galim F, Huitron-Resendiz S, Piña-Crespo JC, Roberts AJ, Verma IM, Sejnowski TJ, and Heinemann SF (2014). Astrocytes contribute to gamma oscillations and recognition memory. Proc Natl Acad Sci USA 111(32): E3343-3352. doi: 10.1073/pnas.1410893111

12. Stehberg J, Moraga-Amaro R, Salazar C, Becerra A, Echeverría C, Orellana JA, Bultynck G, Ponsaerts R, Leybaert L, Simon F, Sa' ez JC, and Retamal MA (2012). Release of gliotransmitters through astroglial connexin 43 hemichannels is necessary for fear memory consolidation in the basolateral amygdala. FASEB J 26(9): 3649-3657. doi: 10.1096/fj.11-198416

13. Ullian EM, Sapperstein SK, Christopherson KS, and Barres BA (2001). Control of synapse number by glia. Science 291(5504): 657661. doi: $10.1126 /$ science.291.5504.657 
14. Koehler RC, Roman RJ, and Harder DR (2009). Astrocytes and the regulation of cerebral blood flow. Trends Neurosci 32(3): 160-169. doi: 10.1016/j.tins.2008.11.005

15. Allen NJ (2014). Astrocyte regulation of synaptic behavior. Annu Rev Cell Dev Biol 30: 439-463. doi: 10.1146/annurev-cellbio-100913013053

16. Volterra A, and Meldolesi J (2005). Astrocytes, from brain glue to communication elements: the revolution continues. Nat Rev Neurosci 6(8): 626-640. doi:10.1038/nrn1722

17. Hamilton NB, and Attwell D (2010). Do astrocytes really exocytose neurotransmitters? Nat Rev Neurosci 11(4): 227-238. doi:

\section{$10.1038 / \mathrm{nrn} 2803$}

18. Attwell D, Buchan AM, Charpak S, Lauritzen M, Macvicar BA, and Newman EA (2010). Glia and Neuronal control of brain blood flow. Nature 468(7321): 232-243. doi:10.1038/nature09613

19. Bélanger M, Allaman I, and Magistretti PJ (2011). Brain energy metabolism: focus on astrocyte-neuron metabolic cooperation. Cell Metab 14(6): 724-738. doi: 10.1016/j.cmet.2011.08.016

20. Pellerin L, and Magistretti PJ (2012). Sweet sixteen for ANLS. J Cereb Blood Flow Metab 32(7): 1152-1166. doi: 10.1038/jcbfm.2011.149

21. Camandola S, and Mattson MP (2017). Brain metabolism in health, aging, and neurodegeneration. EMBO J 36(11): 1474-1492. doi: 10.15252/embj. 201695810

22. Dafny N, and Feldman S (1970). Unit responses and convergence of sensory stimuli in the hypothalamus. Brain Res 17(2):243-527. doi 10.1016/0006-8993(70)90080-6

23. Bonnavion $P$, Mickelsen LE, Fujita A, de Lecea L, and Jackson AC (2016). Hubs and spokes of the lateral hypothalamus: cell types, circuits and behavior. J Physiol 594(22): 6443-6462. doi: $10.1113 / J P 271946$

24. Cornejo MP, Hentges ST, Maliqueo M, Coirini H, Becu-Villalobos D, and Elias CF (2016) Neuroendocrine Regulation of Metabolism. J Neuroendocrinol 28(7). doi: 10.1111/jne.12395

25. Stuber GD, and Wise RA (2016). Lateral hypothalamic circuits for feeding and reward. Nat Neurosci 19(2): 198-205. doi: $10.1038 /$ nn. 4220

26. Broadwell RD, and Brightman MW (1976). Entry of peroxidase into neurons of the central and peripheral nervous systems from extracerebral and cerebral blood. J Comp Neurol 166(3):257-283. doi: 10.1002/cne.901660302

27. Miyata S (2015). New aspects in fenestrated capillary and tissue dynamics in the sensory circumventricular organs of adult brains. Front Neurosci 9:390. doi: 10.3389/fnins.2015.00390

28. Shaver SW, Pang JJ, Wainman DS, Wall KM, and Gross PM (1992) Morphology and function of capillary networks in subregions of the rat tuber cinereum. Cell Tissue Res 267(3): 437-448. doi: 10.1007/bf00319366

29. Ciofi P, Garret M, Lapirot O, Lafon P, Loyens A, Prévot V, and Levine JE (2009). Brain-endocrine interactions: a microvascular route in the mediobasal hypothalamus. Endocrinology 150(12): 5509-5519. doi: 10.1210/en.2009-0584

30. Oomura Y, Kimura K, Ooyama H, Maeno T, Iki M, and Kuniyoshi M (1964). Reciprocal activities of the ventromedial and lateral hypothalamic areas of cats. Science 143(3605): 484-485. doi: 10.1126/science.143.3605.484

31. Chari M, Yang CS, Lam CK, Lee K, Mighiu P, Kokorovic A, Cheung GW, Lai TY, Wang PY, and Lam TK (2011). Glucose transporter-1 in the hypothalamic glial cells mediates glucose sensing to regulate glucose production in vivo. Diabetes 60(7): 1901-6. doi: 10.2337/db11-0120

32. Stolarczyk E, Guissard C, Michau A, Even PC, Grosfeld A, Serradas $P$, Lorsignol A, Pénicaud L, Brot-Laroche E, Leturque A, Le Gall M (2010). Detection of extracellular glucose by GLUT2 contributes to hypothalamic control of food intake. Am J Physiol Endocrinol Metab 298(5): E1078-1087. doi: 10.1152/ajpendo.00737.2009

33. Bady I, Marty N, Dallaporta M, Emery M, Gyger J, Tarussio D, Foretz $M$, and Thorens $B$ (2006). Evidence from glut2-null mice that glucose is a critical physiological regulator of feeding. Diabetes 55(4): 988-995. doi: 10.2337/diabetes.55.04.06.db05-1386

34. Marty N, Dallaporta M, Foretz M, Emery M, Tarussio D, Bady I, Binnert C, Beermann F, Thorens B (2005). Regulation of glucagon secretion by glucose transporter type 2 (glut2) and astrocytedependent glucose sensors. J Clin Invest 115(12): 3545-3553. doi: $10.1172 / \mathrm{JCl} 26309$

35. Verkhratsky A (2010). Physiology of neuronal-glial networking. Neurochem Int 7(4): 332-343. doi: 10.1016/j.neuint.2010.02.002

36. Allard C, Carneiro L, Grall S, Cline BH, Fioramonti X, Chrétien C, Baba-Aissa F, Giaume C, Pénicaud L, and Leloup C (2014). Hypothalamic astroglial connexins are required for brain glucose sensing-induced insulin secretion. J Cereb Blood Flow Metab 34(2): 339-46. doi: 10.1038/jcbfm.2013.206

37. Edmond J (1992). Energy metabolism in developing brain cells. Can J Physiol Pharmacol 70(Suppl): S118 - S129. doi: 10.1139/y92-253

38. Hawkins RA, and Biebuyck JF (1979). Ketone bodies are selectively used by individual brain regions. Science 205(4403): 325-327. doi: $10.1126 /$ science. 451608

39. Taïb B, Bouyakdan K, Hryhorczuk C, Rodaros D, Fulton S, and Alquier T (2013). Glucose regulates hypothalamic long-chain fatty acid metabolism via AMP-activated kinase (AMPK) in neurons and astrocytes. J Biol Chem. 288(52): 37216-37229. doi: 10.1074/jbc.M113.506238

40. Le Foll C, Dunn-Meynell AA, Miziorko HM, and Levin BE (2014). Regulation of hypothalamic neuronal sensing and food intake by ketone bodies and fatty acids. Diabetes. 63(4): 1259-69. doi: $10.2337 / \mathrm{db} 13-1090$

41. Shen L, Tso P, Woods SC, Clegg DJ, Barber KL, Carey K, and Liu M (2008). Brain apolipoprotein E: an important regulator of food intake in rats. Diabetes 57(8): 2092-2098. doi: 10.2337/db08-0291

42. Mauch DH, Nagler K, Schumacher S, Goritz, Muller EC, Otto A, and Pfrieger FW (2001). CNS synaptogenesis promoted by glia-derived cholesterol. Sience 294 (5545): 1354-1357. doi:10.1126/science.294.5545.1354

43. Shen L, Tso P, Wang DQ, Woods SC, Davidson WS, Sakai R, and Liu $M$ (2009). Up-regulation of apolipoprotein $E$ by leptin in the hypothalamus of mice and rats. Physiol Behav 98(1-2): 223-228. doi: 10.1016/j.physbeh.2009.05.013

44. Narishima R, Yamasaki M, Hasegawa S, Yoshida S, Tanaka S, and Fukui T (2011). Leptin controls ketone body utilization in hypothalamic neuron. Neurosci Lett 490(3): 185-190. doi:

10.1016/j.neulet.2010.11.081

45. Diano S, Kalra SP, and Horvath TL (1998). Leptin receptor immunoreactivity is associated with the Golgi apparatus of hypothalamic neurons and glial cells. J Neuroendocrinol 10(9): 647-650. PMID: 9744481

46. Cheunsuang $O$, and Morris $R$ (2005). Astrocytes in the arcuate nucleus and median eminence that take up a fluorescent dye from the circulation express leptin receptors and neuropeptide $Y \mathrm{Y} 1$ receptors. Glia 52(3): 228-233. doi: 10.1002/glia.20239 
47. Fuente-Martín E, García-Cáceres C, Argente-Arizón P, Díaz F, Granado M, Freire-Regatillo A, Castro-González D, Ceballos ML, Frago LM, Dickson SL, Argente J, Chowen JA (2016). Ghrelin Regulates Glucose and Glutamate Transporters in Hypothalamic Astrocytes. Sci Rep 30(6): 23673. doi: 10.1038/srep23673

48. Cardona-Gómez GP, DonCarlos L, and Garcia-Segura LM (2000). Insulin-like growth factor I receptors and estrogen receptors colocalize in female rat brain. Neuroscience 99(4): 751-760. doi: 10.1016/s03064522(00)00228-1

49. Dezonne RS, Lima FR, Trentin AG, and Gomes FC (2015). Thyroid hormone and astroglia: endocrine control of the neural environment. J Neuroendocrinol 27(6): 435-445. doi: 10.1111/jne.12283

50. Reiner DJ, Mietlicki-Baase EG, McGrath LE, Zimmer DJ, Bence KK, Sousa GL, Konanur VR, Krawczyk J, Burk DH, Kanoski SE, Hermann GE, Rogers RC, and Hayes MR (2016). Astrocytes Regulate GLP-1 ReceptorMediated Effects on Energy Balance. J Neurosci 36(12): 3531-3540. doi: 10.1523/JNEUROSCI.3579-15.2016

51. García-Cáceres C, Quarta C, Varela L, Gao Y, Gruber T, Legutko B, Jastroch M, Johansson P, Ninkovic J, Yi CX, Le Thuc O, Szigeti-Buck K, Cai W, Meyer CW, Pfluger PT, Fernandez AM, Luquet S, Woods SC, Torres-Alemán I, Kahn CR, Götz M, Horvath TL, and Tschöp MH (2016). Astrocytic Insulin Signaling Couples Brain Glucose Uptake with Nutrient Availability. Cell 166(4): 867-880. doi: 10.1016/j.cell.2016.07.028

52. García-Cáceres C, Fuente-Martín E, Burgos-Ramos E, Granado M, Frago LM, Barrios V, Horvath T, Argente J, and Chowen JA (2011). Differential acute and chronic effects of leptin on hypothalamic astrocyte morphology and synaptic protein levels. Endocrinology 152(5): 1809-1818. doi: 10.1210/en.2010-1252

53. Fuente-Martín E, García-Cáceres $C$, Granado M, de Ceballos ML, Sánchez-Garrido MÁ, Sarman B, Liu ZW, Dietrich MO, Tena-Sempere M, Argente-Arizón P, Díaz F, Argente J, Horvath TL, and Chowen JA (2012). Leptin regulates glutamate and glucose transporters in hypothalamic astrocytes. J Clin Invest 122(11): 3900-3913. doi: $10.1172 / \mathrm{JCl} 64102$

54. Horvath TL, Sarman B, García-Cáceres C, Enriori PJ, Sotonyi P, Shanabrough M, Borok E, Argente J, Chowen JA, Perez-Tilve D, Pfluger PT, Brönneke HS, Levin BE, Diano S, Cowley MA, and Tschöp MH (2010). Synaptic input organization of the melanocortin system predicts diet-induced hypothalamic reactive gliosis and obesity. Proc Natl Acad Sci U S A 107(33): 14875-14880. doi: 10.1073/pnas.1004282107

55. Kim JG, Suyama S, Koch M, Jin S, Argente-Arizon P, Argente J, Liu ZW, Zimmer MR, Jeong JK, Szigeti-Buck K, Gao Y, Garcia-Caceres C, Yi CX, Salmaso N, Vaccarino FM, Chowen J, Diano S, Dietrich MO, Tschöp $\mathrm{MH}$, and Horvath TL (2014). Leptin signaling in astrocytes regulates hypothalamic neuronal circuits and feeding. Nat Neurosci 17(7): 908910. doi: $10.1038 / \mathrm{nn} \cdot 3725$

56. Kim JD, Leyva S, Diano S (2014). Hormonal regulation of the hypothalamic melanocortinsystem. Front Physiol 5: 480. doi: 10.3389/fphys. 2014.00480

57. Jayaram B, Pan W, Wang Y, Hsuchou H, Mace A, CornelissenGuillaume GG, Mishra PK, Koza RA, and Kastin AJ (2013). Astrocytic leptin-receptor knockout mice show partial rescue of leptin resistance in diet-induced obesity. J Appl Physiol 114(6): 734-41. doi: 10.1152/japplphysiol.01499.2012

58. Hsuchou H, Pan W, Barnes MJ, and Kastin AJ (2009). Leptin receptor mRNA in rat brain astrocytes. Peptides 30(12): 2275-2280. doi:10.1016/j.peptides.2009.08.023

59. Yang L, Qi Y, and Yang Y (2015). Astrocytes control food intake by inhibiting AGRP neuron activity via adenosine A1 receptors. Cell Rep 11(5): 798-807. doi: 10.1016/j.celrep.2015.04.002
60. Sweeney P, Qi Y, Xu Z, Yang Y (2016). Activation of hypothalamic astrocytes suppresses feeding without altering emotional states. Glia 64(12): 2263-2273. doi: 10.1002/glia.23073

61. Cranston I, Marsden P, Matyka K, Evans M, Lomas J, Sonksen P, Maisey M, and Amiel SA (1998). Regional differences in cerebral blood flow and glucose utilization in diabetic man: the effect of insulin. J Cereb Blood Flow Metab 18(2): 130-140. doi: 10.1097/00004647-199802000-00002

62. Hasselbalch SG, Knudsen GM, Videbaek C, Pinborg LH, Schmidt JF, Holm S, and Paulson OB (1999). No effect of insulin on glucose bloodbrain barrier transport and cerebral metabolism in humans. Diabetes 48(10): 1915-1921. doi: 10.2337/diabetes.48.10.1915

63. Woods SC, Lotter EC, McKay LD, and Porte D Jr (1979). Chronic intracerebroventricular infusion of insulin reduces food intake and body weight of baboons. Nature 282(5738): 503-505. doi: $10.1038 / 282503 a 0$

64. Brüning JC, Gautam D, Burks DJ, Gillette J, Schubert M, Orban PC, Klein R, Krone W, Müller-Wieland D, and Kahn CR (2000). Role of brain insulin receptor in control of body weight and reproduction. Science 289(5487): 2122-2125. doi: 10.1126/science.289.5487.2122

65. Zagni E, Simoni L, and Colombo D (2016). Sex and gender differences in central nervous system-related disorders. Neurosci J 2016: 2827090. doi: 10.1155/2016/2827090

66. Chowen JA, Busiguina S, and García-Segura LM (1995). Sexual dimorphism and sex steroid modulation of glial fibrillary acidic protein messenger RNA and immunoreactivity levels in the rat hypothalamus. Neuroscience 69(2): 519-532. doi: 10.1016/0306-4522(95)00250-m

67. Goldstein JM, Seidman L, Horton NJ, Makris N, Kennedy DN, Caviness VS Jr, Faraone SV, and Tsuang MT (2001). Normal sexual dimorphism of the adult human brain assessed by in vivo magnetic resonance imaging. Cereb Cortex 11(6):490-497. doi:

10.1093/cercor/11.6.490

68. Johnson RT, Breedlove SM, and Jordan CL (2008). Sex differences and laterality in astrocyte number and complexity in the adult rat medial amygdala. J Comp Neurol 511(5): 599-609. doi: 10.1002/cne.21859

69. Mong JA, Glaser E, and McCarthy MM (1999). Gonadal steroids promote glial differentiation and alter neuronal morphology in the developing hypothalamus in a regionally specific manner. J Neurosci 19(4): 1464-1472. doi: 10.1523/jneurosci.19-04-01464.1999

70. Mong JA, and McCarthy MM (2002). Ontogeny of sexually dimorphic astrocytes in the neonatal rat arcuate. Brain Res Dev Brain Res 139(2):151-158. doi: 10.1016/s0165-3806(02)00541-2

71. Pfaff D, and Keiner M (1973). Atlas of estradiol-concentrating cells in the central nervous system of the female rat. J Comp Neurol 151(2): 121-158. doi:10.1002/cne.901510204

72.Melcangi RC, Magnaghi V, Galbiati M, and Martini L (2001). Glial cells: a target for steroid hormones. Prog Brain Res 132: 31-40. doi: 10.1016/S0079-6123(01)32063-0

73.Garcia-Ovejero D, Azcoitia I, Doncarlos LL, Melcangi RC, and GarciaSegura LM (2005). Glia-neuron crosstalk in the neuroprotective mechanisms of sex steroid hormones. Brain Res Brain Res Rev 48(2): $273-$ 286. doi: 10.1016/j.brainresrev.2004.12.018

74. Chowen JA, Argente-Arizón P, Freire-Regatillo A, and Argente J (2018). Sex differences in the neuroendocrine control of metabolism and the implication of astrocytes. Front Neuroendocrinol 48: 3-12. doi: 10.1016/j.yfrne.2017.05.003

75. Gulinello M, and Etgen AM (2005). Sexually dimorphic hormonal regulation of the gap junction protein, $\mathrm{CX} 43$, in rats and altered fe- 
male reproductive function in CX43+/- mice. Brain Res 1045(1-2): 107115. doi: 10.1016/j.brainres.2005.03.021

76. Baroncini M, Allet C, Leroy D, Beauvillain JC, Francke JP, and Prevot $\checkmark$ (2007). Morphological evidence for direct interaction between gonadotrophin-releasing hormone neurones and astroglial cells in the human hypothalamus. J Neuroendocrinol 19(9): 691-702. doi: 10.1111/j.1365-2826.2007.01576.x

77. Baroncini M, Jissendi P, Catteau-Jonard S, Dewailly D, Pruvo JP, Francke JP, and Prevot V (2010). Sex steroid hormones-related structural plasticity in the human hypothalamus. Neuroimage 50(2): 428433. doi: 10.1016/j.neuroimage.2009.11.074

78. Witkin JW, Ferin M, Popilskis SJ, and Silverman AJ (1991). Effects of gonadal steroids on the ultrastructure of $\mathrm{GnRH}$ neurons in the rhesus monkey: synaptic input and glial apposition. Endocrinology 129(2): 1083-1092. doi: 10.1210/endo-129-2-1083

79. Mong JA, Nunez JL, McCarthy MM (2002). GABA mediates steroidinduced astrocyte differentiation in the neonatal rat hypothalamus. J Neuroendocrinol 14: 1-16. doi: 10.1046/j.1365-2826.2002.00737.x

80. Musatov S, Chen W, Pfaff DW, Mobbs CV, Yang XJ, Clegg DJ, Kaplitt $M G$, and Ogawa $S$ (2007). Silencing of estrogen receptor alpha in the ventromedial nucleus of hypothalamus leads to metabolic syndrome. Proc Natl Acad Sci U S A 104(7): 2501-2506. doi: 10.1073/pnas.0610787104

81. Xu Y, Elmquist JK, and Fukuda M (2011). Central nervous control of energy and glucose balance: focus on the central melanocortin system. Ann N Y Acad Sci 1243: 1-14. doi: 10.1111/j.17496632.2011.06248.x

82. Barr $\mathrm{SI}$, Janelle $\mathrm{KC}$, and Prior JC (1995). Energy intakes are higher during the luteal phase of ovulatory menstrual cycles. Am J Clin Nutr 61(1): 39-43. doi:10.1093/ajcn/61.1.39

83. Johnson WG, Corrigan SA, Lemmon CR, Bergeron KB, and Crusco $\mathrm{AH}$ (1994). Energy regulation over menstrual cycle. Physiology and Behavior 56: 523-527. doi: 10.1016/0031-9384(94)90296-8

84. Louwe MC, van der Hoorn JW, van den Berg SA, Jukema JW, Romijn JA, van Dijk KW, Rensen PC, Smit JW, and Steendijk P (2012). Gender-dependent effects of high-fat lard diet on cardiac function in C57BI/6J mice. Appl Physiol Nutr Metab 37(2): 214-224. doi: 10.1139/h11-153

85. Morselli E, Criollo A, Rodriguez-Navas C, and Clegg DJ (2014). Chronic High Fat Diet Consumption Impairs Metabolic Health of Male Mice. Inflamm Cell Signal 1(6): e561. doi: 10.14800/ics.561

86. Morselli E, Frank AP, Palmer BF, Rodriguez-Navas C, Criollo A, and Clegg DJ (2016). A sexually dimorphic hypothalamic response to chronic high-fat diet consumption. Int J Obes 40(2): 206-209. doi: 10.1038/ijo.2015.114

87. Morselli E, Fuente-Martin E, Finan B, Kim M, Frank A, GarciaCaceres C, Navas CR, Gordillo R, Neinast M, Kalainayakan SP, Li DL, Gao Y, Yi CX, Hahner L, Palmer BF, Tschöp MH, and Clegg DJ (2014). Hypothalamic PGC-1 $\alpha$ protects against high-fat diet exposure by regulating ER $\alpha$. Cell Rep 9(2): 633-645. doi: 10.1016/j.celrep.2014.09.025

88. Heine PA, Taylor JA, Iwamoto GA, Lubahn DB, and Cooke PS (2000). Increased adipose tissue in male and female estrogen receptor alpha knockout mice. Proc Natl Acad Sci U S A 97(23): 12729-12734. doi: 10.1073/pnas.97.23.12729
89. Micevjch P, and Sinchak K (2008). Estradiol regulation of progesterone synthesis in the brain. Mol Cell Endocrinol 290 (1-2): 44-50. doi: 10.1016/j.mce.2008.04.016

90. Corpechot C, Young J, Calvel M, Wehrey C, Veltz JN, Touyer G, Mouren M, Prasad VV, Banner C, and Sjovall J (1993). Neurosteroids: 3 alpha-hydroxy-5 alpha-pregnan-20-one and its precursors in the brain, plasma, and steroidogenic glands of male and female rats. Endocrinology 133: 1003-1009. doi:10.1210/endo.133.3.8365352

91. Kuo J, Hamid N, Bondar G, Dewing P, Clarkson J, and Micevych P (2010). Sex differences in hypothalamic astrocyte response to estradiol stimulation. Biol Sex Differ 1(1): 7. doi: 10.1186/2042-6410-1-7

92. Frye CA (2009). Neurosteroids' effects and mechanisms for social, cognitive, emotional, and physical functions. Psychoneuroendocrinology 34 (Suppl 1): S143-161. doi: 10.1016/j.psyneuen.2009.07.005

93. Schüle C, Nothdurfter C, and Rupprecht R (2014). The role of allopregnanolone in depression and anxiety. Prog Neurobiol 113: 79-87. doi: 10.1016/j.pneurobio.2013.09.003

94. Coronel MF, Labombarda F, González SL (2016). Neuroactive steroids, nociception and neuropathic pain: A flashback to go forward. Steroids 110: 77-87. doi: 10.1016/j.steroids.2016.04.005

95. Terán-Pérez G, Arana-Lechuga Y, Esqueda-León E, SantanaMiranda R, Rojas-Zamorano JÁ, Velázquez Moctezuma J (2012). Steroid hormones and sleep regulation. Mini Rev Med Chem 12(11): 1040-1048. PMID: 23092405

96. Menozzi R, Florio P, Bondi M, Luisi S, Cobellis L, Genazzani AR, Del Rio $G$, and Petraglia F (2002). Increased response of plasma allopregnanolone to corticotropin-releasing hormone in obese patients. Neuroendocrinology 75: 124-129. doi: 10.1159/000048228

97. Holmberg E, Johansson M, Bäckström T, and Haage D (2014). Allopregnanolone preferentially induces energy-rich food intake in male Wistar rats. Physiol Rep 2(12): e12190. doi: 10.14814/phy2.12190

98. Holmberg E, Sjöstedt J, Malinina E, Johansson M, Turkmen S, Ragagnin $G$, Lundqvist A, Löfgren $M$, Jaukkuri L, Bixo $M$, Bäckström $T$ (2018). Allopregnanolone involvement in feeding regulation, overeating and obesity. Front Neuroendocrinol 48: 70-77. doi:

10.1016/j.yfrne.2017.07.002

99. Belelli D, and Lambert JJ (2005). Neurosteroids: endogenous regulators of the GABA(A) receptor. Nat Rev Neurosci 6(7): 565-575. doi: $10.1038 /$ nrn1703

100. Dietrich MO, and Horvath TL (2009). GABA keeps up an appetite for life. Cell 137(7): 1177-1179. doi: 10.1016/j.cell.2009.06.002

101. Zhang Y, Reichel JM, Han C, Zuniga-Hertz JP, and Cai D (2017). Astrocytic Process Plasticity and IKK $\beta / \mathrm{NF}-\mathrm{KB}$ in Central Control of Blood Glucose, Blood Pressure, and Body Weight. Cell Metab 25(5): 1091-1102. doi: 10.1016/j.cmet.2017.04.002

102. Vercruysse $P$, Vieau $D$, Blum $D$, Petersén $\AA$, and Dupuis $L$ (2018). Hypothalamic alterations in neurodegenerative diseases and their relation to abnormal energy metabolism. Front Mol Neurosci 11:2. doi: 10.3389/fnmol.2018.00002 